\title{
Fast-heating-induced Formation of Metallic-Glass/Crystal Composites with Enhanced Plasticity
}

\author{
Jiri Orava ${ }^{1, *}$, Ivan Kaban ${ }^{1}$, Monika Benkocka ${ }^{2}$, Xiaoliang Han ${ }^{1}$, Ivan Soldatov ${ }^{3}$ and A. Lindsay \\ Greer $^{4}$
}

\author{
${ }^{1}$ IFW Dresden, Institute for Complex Materials, Helmholtzstraße 20, Dresden 01069, Germany \\ ${ }^{2} J$. E. Purkyne University in Usti nad Labem, Faculty of Science, Ceske mladeze 8, Usti nad \\ Labem 400 96, Czech Republic \\ ${ }^{3}$ IFW Dresden, Institute for Metallic Materials, Helmholtzstraße 20, Dresden 01069, Germany \\ ${ }^{4}$ Department of Materials Science and Metallurgy, University of Cambridge, 27 Charles Babbage \\ Road, Cambridge CB3 OFS, United Kingdom \\ *The corresponding author: j.orava@ifw-dresden.de
}

\begin{abstract}
Bulk metallic glasses are known to have poor plasticity which limits their application as structural materials. Due to the lack of atomic periodicity in metallic glasses, their mechanical properties cannot be controlled the same way as in crystalline materials. Fast-heating-induced, a heating rate of $10 \mathrm{~K} \mathrm{~s}^{-1}$ and higher, crystallization of ductile nanocrystalline phase(s) leads to enhanced plasticity of metallic-glass/crystal composites. Here, an overview of controlling the microstructure on fast heating, the suggested crystallization mechanism of metastable phases and the principle of enhanced plasticity of the composites is presented and discussed, with a special focus on $\mathrm{Cu}-\mathrm{Zr}-$ based metallic glasses.
\end{abstract}

\section{Introduction}

Metallic glasses (MGs), formed by quenching a liquid with a wide range of cooling rates $\sim 10^{-3}-10^{7} \mathrm{~K} \mathrm{~s}^{-1}$, are of fundamental interest because of their mechanical properties such as reversible large elastic energy storage, high hardness giving good wear resistance, and high 
toughness [1]; their soft magnetic properties [2]; and their potential biocompatibility as (non)degradable implants [3].

However, due to the lack of atomic periodicity and microstructure in MGs, unlike in conventional polycrystalline alloys, at least in the standard view of grains, their boundaries and defects, mechanical properties of MGs cannot be controlled the same way as in crystalline materials. For metallic glasses, the initial mechanical deformation is localized in small nanometerlength scale regions, initially $\sim 10-20 \mathrm{~nm}$ thick, called shear bands [4]. Shear bands form in highereffective-mobility volumes, containing from a few units to a few tens of atoms [5] called sheartransformation or liquid-like zones, by their cooperative response to the deformation. When initiated, a single shear band can quickly propagate via a self-promoting mechanism $[4,6]$ leading to a crack development, and resulting in catastrophic failure of monolithic bulk metallic glasses (BMGs). The crack formation may be accompanied by a short $\sim 5-15 \mu$ s temperature rise not exceeding the melting point $\left(T_{\mathrm{m}}\right)$ of a material, as shown for $\mathrm{Zr}_{65} \mathrm{Cu}_{25} \mathrm{Al}_{10} \mathrm{MG}$ (here and throughout the manuscript in at.\%) by Das et al. [7]. Typically, monolithic BMGs exhibit a compressive yield strain, elastic strain limit, of $\varepsilon_{\mathrm{e}} \sim 2 \%$, and a nearly-zero plastic strain, which limits their application as structural materials [8].

The plasticity of BMGs is improved by imposing uniformly-distributed flow (not localized in a single shear band) [9], i.e. multiple shear bands with a finer pattern are formed and a branching of shear bands is created. In other words, shear band initiation and propagation, the latter delaying the onset of a crack formation, have to be inhibited and controlled. Exploiting such "empirical" principles, Schroers and Johnson [10] demonstrated remarkable $\varepsilon_{\mathrm{p}} \approx 20 \%$ in compression for the monolithic $\mathrm{Pt}_{57.5} \mathrm{Cu}_{14.7} \mathrm{Ni}_{5.3} \mathrm{P}_{22.5}$ glass.

Melt-quenched MGs contain intrinsic structural heterogeneities [11], sometimes referred to as 'soft spots', by those we mean locally favored structures different from the matrix major structure, and which are also inherent to the supercooled liquid, referred to as dynamic heterogeneities [12]. Here, we ignore the role of the evolving dynamic heterogeneities on the crystallization process [13]. Liu et al. [14] showed that some types of these intrinsic heterogeneities to MGs can be detected as $\sim 2 \mathrm{~nm}$-size domains, though their size is somewhat probe-size dependent, with large energy dissipation and an average difference in viscoelasticity around $12 \%$ in sputtered thin-film $\mathrm{Zr}_{55} \mathrm{Cu}_{30} \mathrm{Ni}_{5} \mathrm{Al}_{10}$. The inherent heterogeneities can be manipulated by applying external stimuli, for example, doing mechanical work via elastic cycling below the yield 
stress [15] and via elastostatic loading [16], or they can be stimulated by thermal cycling of MGs between room and liquid-nitrogen temperatures as shown, for example, for $\mathrm{Cu}-\mathrm{Zr}$-based BMGs $[17,18]$. Commonly for all the above noted methods, depending on the initial glassy state and detailed experimental conditions, the stimuli can lead either to relaxation or rejuvenation of the glass [19]. Relaxation gives embrittlement of MGs. Rejuvenation, with the stored energy as high as $60 \%$ of the enthalpy of melting in the glass, e.g., for $\mathrm{Zr}_{58.5} \mathrm{Cu}_{15.6} \mathrm{Ni}_{12.8} \mathrm{Al}_{10.3} \mathrm{Nb}_{2.8} \mathrm{MG}$ [20], can give profound increase in the size, population and broadening of the relaxation spectrum of denser and softer heterogeneities resulting in enhanced plasticity [19]. Phase separation, generating regions forcing shear-band branching and multiplication, can also be used to enhance plasticity and there are many examples for $\mathrm{Cu}-\mathrm{Zr}$-based glasses [21].

Instead of directly exploiting the inherent heterogeneities of MGs, they can also be induced externally, for example, by imprinting the surface of a glass inducing macroscopic distribution of elastic heterogeneity in the bulk [22], or by in-situ thermal growth of nanometer-to-micrometer size crystalline phases - the latter is the focus of this overview paper. The plasticity is enhanced by introducing homogeneously dispersed ductile crystalline phase(s) in the glassy matrix, while the yield strength is typically reduced for such composites. Fast-heating (flash annealing) techniques, by which we can apply a heating rate $\Phi>10 \mathrm{~K} \mathrm{~s}^{-1}$, have been reported as appropriate tools for controlling metallic-glasses microstructures by forming glass/crystal composites. So far, fast heating has mostly been applied to multicomponent $\mathrm{Cu}-\mathrm{Zr}$-based metallic glasses and we restrict ourselves mainly to these alloys. Alloying of the binary system with $\mathrm{Al}, \mathrm{Ni}, \mathrm{Co}$ and other elements greatly improves the glass-forming ability [23]. For example, a glassy rod of 22-mm diameter, $\phi$, [24] of the eutectic $\mathrm{Zr}_{50} \mathrm{Cu}_{40} \mathrm{Al}_{10} \mathrm{BMG}$ could be prepared with the temperature range of the existence of the supercooled liquid, before the onset of crystallization takes place on heating, of $\approx 100 \mathrm{~K}$ [25]. For the equimolar binary system, a glassy rod of up to $\phi=2 \mathrm{~mm}$ only, corresponding to cooling rate of about $250 \mathrm{~K} \mathrm{~s}^{-1}$, could be obtained [26].

Just to note that flash annealing is of great importance for preparing soft-magnetic Fe-based glass/crystal-composite ribbons, such as FINEMET glass $\mathrm{Fe}_{73.5} \mathrm{Si}_{13.5} \mathrm{~B}_{9} \mathrm{Nb}_{3} \mathrm{Cu}_{1}$, which are used as a winding in transformers because of their low energy losses. The in-situ flash annealing during ribbon casting induces the growth of soft-magnetic $\mathrm{Fe}_{3} \mathrm{Si}$ crystalline nanoparticles of the size of $10-15 \mathrm{~nm}$. This topic is beyond the scope of the paper; a recent overview can be found in Ref. [27]. 
The paper is structured as follows. Section 2 presents the preparation of metallic-glass/crystal composites from a melt by controlling the cooling step. The relation between the presence, type and fraction of crystalline phases and the composite plasticity is discussed. We then present the recent work on fast-heating-induced composites obtained from glassy state, i.e. heating rate ranging from a few tens to a few millions of $\mathrm{K} \mathrm{s}^{-1}$ in Sect. 3. The suggested mechanisms of the fast crystallization and of the enhanced plasticity are discussed in Sects. 3.1 and 3.2, respectively.

\section{Controlling the microstructure on cooling}

We will firstly discuss controlling the microstructure by defined cooling methods - cooling rates of up to $10^{6}-10^{7} \mathrm{~K} \mathrm{~s}^{-1}$ can be achieved for melt-spun ribbons. Not only have these methods kindled the interest in the field of glass/crystal composites for improving the macroscopic deformability, but they have also provided some (semi)-quantitative analysis of the crystallization mechanisms and kinetics. A recent development of the fast-heating/cooling ( $\pm 10^{6} \mathrm{~K} \mathrm{~s}^{-1}$ [28]) flash calorimetry, developed by Prof. C. Schick and co-workers [29], has opened up possibilities for quantitative analysis of nucleation and crystal-growth rates over a wide temperature range of the existence of the supercooled liquid for MGs. So far, the calorimetry has been limited to low-melting systems, below $520^{\circ} \mathrm{C}$, for example, to Au-based metallic glasses [30]. The further development in heating rates and high-temperature limits [31] will certainly bring new insights into the crystallization of the high-temperature BMGs reviewed here.

The equilibrium phase diagram of the binary $\mathrm{Cu}-\mathrm{Zr}$ system is shown in Figure 1 [32], and Table 1 lists the reported metastable phases found in this system [33]. We will refer to this binary diagram even for multicomponent $\mathrm{Cu}-\mathrm{Zr}$-based alloys, because the crystalline phases controlling the plasticity of the composites are rather similar. The individual multicomponent diagrams can routinely be found in the ASM Alloy Phase Diagram Database [41], or in Ref. [42]; the latter being focused on the ternary $\mathrm{Cu}-\mathrm{Zr}-\mathrm{Al}$ system. The binary equimolar metallic glass $\mathrm{Cu}_{50} \mathrm{Zr}_{50}$ has $\varepsilon_{\mathrm{p}}$ of less than $1 \%$ [24]. Introducing small spherical nanocrystals, $\phi=1-2 \mathrm{~nm}$, results in a compressive plastic strain of 7.9\% [43]. Inoue et al. [24] showed that $\varepsilon_{\mathrm{p}}$ can be as much as $52 \%$ in a compression by introducing evenly dispersed nanocrystals, $5-10 \mathrm{~nm}$ in a diameter, of the metastable $\mathrm{Cu}_{5} \mathrm{Zr}$ phase (not shown in Figure 1) in the parental glass. Such a high plastic strain achieved was 
attributed to the suppression of shear softening of BMGs through the crystal coalescence without the phase transformation of the $\mathrm{Cu}_{5} \mathrm{Zr}$ phase.

Pauly et al. [44] studied the formation and the role of the austenitic high-temperature $\mathrm{B} 2-\mathrm{CuZr}$ phase $(\mathrm{Pm} \overline{3} \mathrm{~m})$, highlighted in red in Figure 1 for the $\mathrm{Cu}-\mathrm{Zr}$ system, on the mechanical properties of $\mathrm{Cu}_{47.5} \mathrm{Zr}_{47.5} \mathrm{Al}_{5} \mathrm{BMG} /$ crystal composites. The congruently melting $\mathrm{B} 2$ phase with the $\mathrm{CsCl}$ prototype is stable between 725 and $960{ }^{\circ} \mathrm{C}$ in the ternary $\mathrm{Cu}-\mathrm{Zr}-\mathrm{Al}$ system [42]. The authors [44] demonstrated a compressive plasticity of up to $10.1 \%$ for rods with $\phi=2 \mathrm{~mm}$ (highest cooling rate in the study) with the crystal size ranging from a few units to a few hundreds of micrometers. The plasticity decreased to $2.3 \%$, the yield strength remained almost the same, with increasing the volume fraction of the crystalline phase; no details were given about the average particles size variation with the cooling rate (rod diameter). This suggests the importance of the microstructure length-scale for plasticity. For dendritic microstructures, Eckert et al. [45] showed that when the microstructure is too fine, i.e. the length of the primary dendrite is $2-6 \mu \mathrm{m}$ with $\phi=0.2-0.4 \mu \mathrm{m}$, then there is no benefit for the plasticity because propagating shear bands cannot be effectively blocked. It seems, that in the optimized dendritic composites the length-scale should be of the order of $100 \mu \mathrm{m}[8]$.

Wu et al. [46] systematically studied the influence of the crystalline phases on the ductility of $\left(\mathrm{Cu}_{0.5} \mathrm{Zr}_{0.5}\right)_{x} \mathrm{Al}_{100-x}$ BMGs. The high-temperature $\mathrm{B} 2-\mathrm{CuZr}$ phase decomposes into the lowtemperature $\mathrm{Cu}_{10} \mathrm{Zr}_{7}$ and $\mathrm{Zr}_{2} \mathrm{Cu}$ phases on cooling (Fig. 1), and the phase(s) present in the glass can be controlled via the cooling rate. Wu et al. [46] showed that the sequence of the as-cast sample microstructure typically varies as: fully glassy (Fig. 2 - full squares), glassy $+\mathrm{B} 2-\mathrm{CuZr}$ (the region containing the diamonds and highlighted by the red dashed line in Figure 2), glassy $+\mathrm{B} 2-\mathrm{CuZr}+$ $\mathrm{Al}_{2} \mathrm{Zr}$ (Fig. 2 - green stars) with decreasing the cooling rate (Fig. 2). The B2 phase could not be formed for alloys containing $\geq 10$ at.\% of $\mathrm{Al}$ [46]. The authors concluded that $\mathrm{B} 2-\mathrm{CuZr}$ improves the ductility and work-hardening of the composite, unlike for the other brittle phases $\left(\mathrm{Al}_{2} \mathrm{Zr}\right.$, etc.) which do not have any helpful contribution to the property (Fig. 2). The ductility could be enhanced from effectively zero to $\sim 2 \%$ for the ternary-alloy composite with 4 at. $\%$ of $\mathrm{Al}$ and containing $\sim 15$ vol.\% of homogeneously dispersed spherical B2 crystals with $\phi=20-100 \mu \mathrm{m}$ (corresponding to the 3-mm diameter rod in Figure 2). For larger crystals, only a small enhancement of ductility $\sim 0.5 \%$ was observed ( $x_{\mathrm{Al}}=4$ at. $\%, \phi=4 \mathrm{~mm}$ in Figure 2$)$. 
Crystallization is generally size-dependent, and this is also true for BMGs [47]. A recent work by Sohn and co-workers [49] demonstrates the possibility for tuning the type of the crystalline phases present in the final microstructure by controlling the $\mathrm{Pt}_{57.5} \mathrm{Cu}_{14.7} \mathrm{Ni}_{5.3} \mathrm{P}_{22.5}$ metallic-glass rod diameter. This BMG shows complex multicomponent crystallization on a macroscopic scale [50]. The authors observed three distinct crystallization mechanisms on cooling when a rod diameter was reduced from a few hundreds to a few tens of nanometers (Fig. 3); the formation of: i) a polycrystalline phase with multiple constituent phases via solute partitioning; ii) a polycrystalline phase with the chemical composition identical to that of the supercooled liquid; and iii) an apparent metastable single-crystalline phase with the same chemical composition to the glass composition. The formation of the apparent single-crystalline phase is rather unexpected. With the limited measured diffraction data available, the phase was identified to adopt a $\mathrm{P}_{2} \mathrm{Pt}_{5}$-like crystal structure. Its formation is speculated to be kinetically driven, higher cooling rates promote appearance of fewer stable nuclei and when the rod diameter is of the same order as the mean distance between the critical nuclei then a single nucleation event may occur stimulating its growth. There is a wellknown asymmetry between the critical cooling and heating rates, the former being typically 1-2 orders of magnitude lower, for glass-forming liquids which originates from the different starting population of nuclei [51]. Because of the influence of the rod size on nucleation and growth rates, it emerges that this asymmetry is also size dependent [49]: i) both critical rates show a nonmonotonic dependence on decreasing a rod diameter; ii) both critical rates have a maximum for 60-nm diameter rod; and iii) the asymmetry disappears for $\phi \leq 45 \mathrm{~nm}$. Therefore, preparing MGs in confined volumes could represent another route for achieving new crystalline phases in BMGs.

\section{Controlling the microstructure on heating}

Fast heating has been done, for example, by resistive Joule heating [52], by inductive heating $[53,54]$ and by capacitance-discharge heating [55] of ribbons and BMGs. Examples of resistiveheating and inductive-heating setups, mainly used to prepare the composites, are shown in Figure 4. The aim of the fast-heating techniques is to obtain homogeneously-dispersed particles in the glass with narrow particle-size distributions of high-temperature phases being beneficial for plasticity. On fast heating/cooling, unlike for conventional heating rates, relaxation of a glass is restricted, which may limit the unwanted embrittlement. In spite of a number of experiments on fast heating/cooling not much is known about the structure of the remaining glassy matrix in the 
composites, and even the experimental conditions (heating/cooling rate, annealing temperature and time etc.) have not been optimized.

Song et al. [57] showed that the $\mathrm{Cu}_{42} \mathrm{Zr}_{42} \mathrm{Al}_{10} \mathrm{Co}_{6} \mathrm{BMG}$ still preserves about $45 \%$ of the enthalpy of relaxation of an as-cast sample when re-heated to the supercooled liquid below the onset of crystallization, and most importantly cooled at $50 \mathrm{~K} \mathrm{~s}^{-1}-$ the decrease in the enthalpy correlates with the lower applied cooling rate contrary to the higher rate applied for casting 2-mm diameter rod. The glass re-heated and cooled at $0.333 \mathrm{~K} \mathrm{~s}^{-1}$ is fully relaxed. A plastic strain of $\sim 2 \%$ could be achieved for $\mathrm{Cu}_{42} \mathrm{Zr}_{42} \mathrm{Al}_{10} \mathrm{Co}_{6}$ glass-crystal composite containing 29 vol. $\%$ of the $\mathrm{B} 2$ phase with an average particle diameter $\phi_{\mathrm{av}} \approx 1.8 \mu \mathrm{m}$ [57]; the glass was heated using an infrared lamp at $\Phi=50 \mathrm{~K} \mathrm{~s}^{-1}$ to $T=994 \mathrm{~K}$ followed by annealing for $t_{\mathrm{a}}=60 \mathrm{~s}$. Kosiba et al. [58] showed preferential crystallization of the $\mathrm{B} 2-\mathrm{CuZr}$ phase in inductively-heated $\mathrm{Cu}_{44} \mathrm{Zr}_{44} \mathrm{Al}_{8} \mathrm{Hf}_{2} \mathrm{Co}_{2} \mathrm{BMG}$ with increasing $\Phi$ from 0.08 to $180 \mathrm{~K} \mathrm{~s}^{-1}$. The low-temperature $\mathrm{Cu}_{10} \mathrm{Zr}_{7}$ and $\mathrm{CuZr}_{2}$ (Fig. 1) phases formed at low heating rates $\leq 16 \mathrm{~K} \mathrm{~s}^{-1}$ only. The critical heating rate to form predominantly the B2 phase is composition-dependent, and for example, the rate can be as low as $\sim 8 \mathrm{~K} \mathrm{~s}^{-1}$ for the $\mathrm{Zr}_{50} \mathrm{Cu}_{40} \mathrm{Al}_{10}$ glass [25]. A glass-crystal composite, prepared by Kosiba et al. [58] containing $\sim 15$ vol. $\%$ of B2 phase and with $\phi_{\mathrm{av}} \approx 10 \mu \mathrm{m}$ formed by heating the glass to $948 \mathrm{~K}$ at $\Phi \approx 180 \mathrm{~K} \mathrm{~s}^{-1}$, showed $\sim 10 \%$ plastic strain in a uniaxial compression, unlike the zero plasticity for the as-cast glass, with some softening at room temperature. When the B2 phase fraction is increased to $\sim 80$ vol.\% then the B2 phase martensitic transformation overcomes the glassy-matrix softening and overall hardening of the composite is observed. Importantly, the fast-heated samples were quenched in a water bath with a cooling rate of $\sim 10^{3} \mathrm{~K} \mathrm{~s}^{-1}$ immediately on turning the heating off; suppressing any phase transformation(s) on cooling and leading to a rather unrelaxed glassy state.

Okulov et al. [52] demonstrated the formation of glass-crystal composites and fully crystalline alloys for resistively-heated $\mathrm{Cu}_{47.5} \mathrm{Zr}_{47.5} \mathrm{Al}_{5.0}$ glassy ribbons. A tensile strain of $6.8 \%$, unlike zero ductility for the as-cast ribbon, with a strong hardening could be achieved in a composite prepared by heating at around $750 \mathrm{~K} \mathrm{~s}^{-1}$ and containing $~ 33$ vol. $\%$ of the B2 phase with $\phi_{\mathrm{av}} \approx 5 \mu \mathrm{m}$. The authors also showed that the mechanical properties of the fully crystalline alloys depend on the microstructure represented by the volume fraction of the $\mathrm{B} 2-\mathrm{CuZr}$ and the stable $\mathrm{Cu}_{10} \mathrm{Zr}_{7}$ phases. The hard, but brittle $\mathrm{Cu}_{10} \mathrm{Zr}_{7}$ phase, mainly formed at low heating rates, strengthens the fully crystalline alloy, and the tough high-temperature $\mathrm{B} 2-\mathrm{CuZr}$ phase, preferentially formed 
at high heating rates, gives rise to plasticity. None of the fast-heating studies, up to the present, have really fully optimized the microstructure to maximize the deformability of metallic glasses.

\subsection{The crystallization mechanism}

The crystallization mechanism and phases evolution on fast devitrification of $\mathrm{Cu}-\mathrm{Zr}$-based glasses remain unclear; details of the individual stages of crystallization on heating, i.e. the nucleation and growth are missing, and the possible transformations in the composites on cooling, typically lasting 2-4 orders of magnitude longer when air-cooled than a millisecond-to-second time-scale heating, remain barely studied. Cullinan et al. [59], and Kalay et al. [33,60] attempted to resolve the crystallization sequence(s) with a focus on the early stages of crystallization in glassy $\mathrm{Cu}_{50} \mathrm{Zr}_{50}[33,59]$ and $\mathrm{Cu}_{56} \mathrm{Zr}_{44}$ [60] alloys. The following stages of crystallization were observed for an isothermal annealing of $\mathrm{Cu}_{50} \mathrm{Zr}_{50}$ at $671 \mathrm{~K}$ [33], a temperature at which the $\mathrm{B} 2$ phase should not be stable (Fig. 1). In the early stages of the isothermal hold, fine $\mathrm{Cu}_{10} \mathrm{Zr}_{7}$ particles were formed. On prolonged annealing, very fine platelets, $10-20 \mathrm{~nm}$ in a length, were observed in the vicinity of the growing $\mathrm{Cu}_{10} \mathrm{Zr}_{7}$ phase accompanied by solute partitioning leading to $\mathrm{Zr}$ enrichment of the surrounding glassy phase. With further increasing of the annealing time, the appearance of a small amount of the $\mathrm{CuZr}_{2}$ and $\mathrm{B} 2-\mathrm{CuZr}$ phases was observed resulting in a four-phase component system with the $\mathrm{Cu}_{10} \mathrm{Zr}_{7} / \mathrm{CuZr}_{2} / \mathrm{B} 2-\mathrm{CuZr}$ crystalline-phases-growth sequence embedded in the glass (Fig. 5a). The $\mathrm{CuZr}_{2}$ phase nucleated on the $\mathrm{Cu}_{10} \mathrm{Zr}_{7} /$ glass interface and grew up to 100 to $150 \mathrm{~nm}$ in length. The $\mathrm{CuZr}_{2}$ then served as a template for an epitaxial-like growth of the $\mathrm{B} 2-\mathrm{CuZr}$ phase within the Zr-rich region in the glass (Fig. 5b). This epitaxial-like templating effectively eliminates the need for the nucleation process and may be just growth-limited. The same crystallization sequence may also be present for other $\mathrm{Cu}-\mathrm{Zr}$-based glasses [61], and it is also believed to occur in the fast heating of $\mathrm{Cu}-\mathrm{Zr}$-based BMGs. Dendrites of the $\mathrm{Cu}_{10} \mathrm{Zr}_{7}$ phase could be detected embedded inside some of the B2-CuZr microcrystals at high heating rates $\sim 700 \mathrm{~K} \mathrm{~s}^{-1}$ [52].

Clearly, at low heating rates, less than $40 \mathrm{~K} \mathrm{~min}^{-1}$, the stable low-temperature $\mathrm{Cu}_{10} \mathrm{Zr}_{7}$ and $\mathrm{CuZr}_{2}$ phases form, and $\mathrm{X}$-ray diffraction studies showed that $\mathrm{Cu}_{10} \mathrm{Zr}_{7}$ growth precedes that for $\mathrm{CuZr}_{2}$ in $\mathrm{Cu}_{47.5} \mathrm{Zr}_{47.5} \mathrm{Al}_{5}$ glassy ribbons [62-64]. Kaban et al. [62] hint on the structural origin of the nucleation sequence by comparing the structures between $\mathrm{Cu}_{47.5} \mathrm{Zr}_{47.5} \mathrm{Al}_{5}$ glass, and $\mathrm{Cu}_{10} \mathrm{Zr}_{7}$, 
$\mathrm{CuZr}_{2}$ and $\mathrm{B} 2-\mathrm{CuZr}$ crystalline phases. The partial radial distribution functions for the $\mathrm{Cu}-\mathrm{Cu}$, $\mathrm{Cu}-\mathrm{Zr}$ and $\mathrm{Zr}-\mathrm{Zr}$ pairs are shown in Figure 6. There seems to be a reasonable similarity for the $\mathrm{Cu}-\mathrm{Cu}$ distributions between the glass and the $\mathrm{Cu}_{10} \mathrm{Zr}_{7}$ phase, and relatively small discrepancy for the $\mathrm{Cu}-\mathrm{Zr}$ and $\mathrm{Zr}-\mathrm{Zr}$ in the first-coordination shell. There is also a structural resemblance for the $\mathrm{Cu}-\mathrm{Zr}$ and $\mathrm{Zr}-\mathrm{Zr}$ pairs between the glass and the $\mathrm{B} 2$ phase within the first-coordination cell - there is also effectively no difference in the density between the two phases [62]. The largest differences in the pair distributions are observed for the glass and the $\mathrm{CuZr}_{2}$ phase. It can also be seen that although the $\mathrm{CuZr}_{2}$ and $\mathrm{B} 2-\mathrm{CuZr}$ phases are essentially different, the position of the first peak of the $\mathrm{Cu}-\mathrm{Cu}$ and $\mathrm{Zr}-\mathrm{Zr}$ pairs is rather similar, probably hinting on the chemical-ordering feasibility of the templated growth during isothermal annealing or slow heating rates (Fig. 5b). However, this may not necessarily hold for rapid heating.

Yasuda et al. [65] showed by electromagnetic levitation that the crystal-growth rate, $U$, does not exceed $1 \times 10^{-3} \mathrm{~m} \mathrm{~s}^{-1}$ at $0.92 T_{\mathrm{m}}\left(T=1079 \mathrm{~K}\right.$ ) for $\mathrm{Zr}_{50} \mathrm{Cu}_{40} \mathrm{Al}_{10}$ BMGs (please note that the growth rate may be overestimated because of the mutual stirring of the supercooled liquid). The final microstructure consisted of the $\mathrm{B} 2, \mathrm{Zr}_{2} \mathrm{Cu}$ and $\tau_{3}$ phases [65]. Computer simulations showed that $U \approx(3-5) \times 10^{-3} \mathrm{~m} \mathrm{~s}^{-1}$ is achieved at $0.88 T_{\mathrm{m}}(T=1000 \mathrm{~K})$ for the $\mathrm{B} 2$ phase in supercooled liquid $\mathrm{Cu}_{47.5} \mathrm{Zr}_{47.5} \mathrm{Al}_{5}$ [66]. The congruent crystal growth in $\mathrm{Cu}_{50} \mathrm{Zr}_{50}$ shows maximum at the homologous temperature of $0.83 T_{\mathrm{m}}(T=1003 \mathrm{~K})$ for which $U=2.3 \times 10^{-2} \mathrm{~m} \mathrm{~s}^{-1}$ [67] - this is about four orders of magnitude lower than the crystal-growth rate achievable in pure metals [68].

The devitrification sequence for $\mathrm{Cu}_{56} \mathrm{Zr}_{44}$ is different from that for $\mathrm{Cu}_{50} \mathrm{Zr}_{50}$ glass. For the $\mathrm{Cu}$-rich glass, Kalay et al. [60] revealed the following crystallization mechanism. On an isokinetic heating, at a rate of $10 \mathrm{~K} \mathrm{~min}^{-1}$, the crystallization started at $725 \mathrm{~K}$ and finished at $728 \mathrm{~K}$ producing a two-phase crystalline product of $\mathrm{Cu}_{10} \mathrm{Zr}_{7}$ and $\mathrm{CuZr}_{2}$ phases. On increasing the temperature, the two-phase structure remained until the onset of the $\mathrm{B} 2-\mathrm{CuZr}$ precipitation and $\mathrm{CuZr}_{2}$ dissolution at $1004 \mathrm{~K}$ (Fig. 1); the three-phase product then remained until the complete dissolution of the $\mathrm{CuZr}_{2}$ phase at $1030 \mathrm{~K}$. Clearly, the $\mathrm{B} 2$ phase did not form below its stable temperature, unlike in glassy $\mathrm{Cu}_{50} \mathrm{Zr}_{50}$, which may indicate the role of the partitioning with the proper $\mathrm{Zr}$ enrichment in the glassy phase for the successful B2 phase growth. A detailed study of the B2-CuZr phase formation and its stability in 36 ternary and quaternary $\mathrm{Cu}-\mathrm{Zr}$-based BMGs can be found in Ref. [69]. 
Crystallization may be greatly affected by the evolving structure of the underlying supercooled liquid. Küchemann and Samwer [55] did not observe any formation of the B2-CuZr phase for $\mathrm{Zr}_{64.0} \mathrm{Cu}_{28.2} \mathrm{Al}_{7.8}$ glassy ribbons when heated with a rate of $\approx 10^{6} \mathrm{~K} \mathrm{~s}^{-1}$ via a capacitor discharge. The ribbons crystallized in the sequence of $\mathrm{Zr}_{2}(\mathrm{Cu}, \mathrm{Al})$ stable phase followed by the formation of $\mathrm{ZrO}_{2}$ when heated at $1 \times 10^{6} \mathrm{~K} \mathrm{~s}^{-1}$. When the heating rate was increased to $1.6 \times 10^{6} \mathrm{~K}$ $\mathrm{s}^{-1}$, the crystallization of the stable $\mathrm{Zr}_{2}(\mathrm{Cu}, \mathrm{Al})$ was bypassed and only the $\mathrm{ZrO}_{2}$ phase formed. For samples heated at $1.6 \times 10^{6} \mathrm{~K} \mathrm{~s}^{-1}$ and faster, the authors suggested the existence of a first-order liquid-liquid phase transition evidenced by the excess in the specific heat capacity just below the melting point; a heat of fusion for the transition is about $62.5 \%$ of the heat of melting. The structural changes taking place in the supercooled liquid may also underlie the non-monotonic dependence of the glass-transition temperature on heating rate for the $\mathrm{Zr}_{65} \mathrm{Cu}_{27.5} \mathrm{Al}_{7.5}$ glassy ribbons [70].

\subsection{The mechanism of the enhanced plasticity}

The mechanism(s) of the plastic deformation of the glass/crystal composites still remains poorly understood and it is not the aim to provide a comprehensive review on this topic. More details can be found, for example, in Refs. [71-73]. In general, different deformation mechanisms may operate on different composite-domain length-scales. For nanocrystalline particles, the deformation may be initiated at the crystal-glass interface, controlled by the properties of an intermediate phase present at the interface, and then dominated by the mechanical properties of the glassy phase [74]. For micrometer-size crystals, the deformation may be initiated in the ductile phase and further deformation is mediated by dislocation movement in the crystalline grains.

The theories of shear-band propagation and improved plasticity are based on many arguments, some of them are given below. Just to note that several mechanisms may operate at a time depending on many factors: strain rate, temperature, crystal size and crystallography, the energy state of the glassy matrix, etc. Free-volume considerations $[75,76]$ argue that rejuvenated glasses show improved plasticity, and introducing a nanocrystalline phase is more efficient in enhancing ductility than increasing free volume. Shear-band propagation can induce crystallization and coalescence of nanocrystals inside shear bands $[74,77,78]$, promoted at a low shear rate, thus being likely thermally activated. In such a case, the shear band must bend/multiply or a new one must nucleate. Body-centered-cubic nanocrystals which can be twinned, the main macroscopic 
deformation mechanism, are less effective in blocking shear-band propagation [74]. The shearband-propagation blocking is efficient for crystalline particles of a sufficient size comparable to the thickness of a shear band. On the other hand, the surrounding region around large particles can serve as a nucleation site for shear bands [79]. The interface between the crystalline nanoparticles and the glassy phase also plays a crucial role in plastic deformation $[66,74,80]$. Moleculardynamics simulations show that the interface is a few atomic-sizes thick, the volume fraction is of the same order of magnitude as the volume fraction of the nanoparticles, and its density is lower than that for the nanoparticles or the glassy phase. The lower-density interface, accompanied by significant decrease in the local shear modulus, can be the primary region of the localized shear deformation.

For the micrometer-size-domain composites, the stress-induced martensitic transformation from the austenitic B2-CuZr to the B19' was suggested to be the mechanism for the enhanced plasticity $[46,81]$. It had been assumed that the volume change on the deformation exerts a compressive stress on the glassy matrix surrounding the crystals suppressing shear bands nucleation [81]. Corteen et al. [82] showed that the volume change is very low with negligible toughening effect thus questioning the above-suggested mechanism. Song et al. [83] showed that a small amount of $\sim 200-300 \mathrm{~nm}$ regions of martensitic plates can already co-exist along the B2 phase in 2-mm diameter rod of $\mathrm{Cu}_{47.5} \mathrm{Zr}_{47.5} \mathrm{Al}_{5}$, containing exceptionally high amount $\sim 80 \mathrm{vol} . \%$ of the crystalline phase. The authors hint on a sequence of the deformation mechanism of such a composite: the elastic limit, lower than the monolithic glass, results from the high volume fraction of the B2 phase and the initiation of the martensitic transformation. On further compression, the plasticity is mainly controlled by the interplay between the ongoing martensitic transformation and shear-bands multiplication inside the glassy phase. The later stages of the deformation are characterized by formation of a high density of dislocations and partial de-twinning. It may be that such a mechanism may still prevail for the composites containing extremely high fraction of very large $\mathrm{B} 2-\mathrm{CuZr}$ particles when the primary deformation is not controlled by the glassy matrix, but it does not operate for nanocrystalline composites.

\section{Conclusions}

Fast-heating techniques that allow control of the microstructure of metallic glasses are of current interest. Knowledge of the crystallization mechanisms on fast heating still remains limited. A heating rate in the range of $10^{6} \mathrm{~K} \mathrm{~s}^{-1}$ can be achieved and the crystallization mechanism is 
kinetically controlled. The solute partitioning that predominates in crystallization on slow heating and isotheral annealing of a glass is unlikely to be the controlling factor for flash annealing. Preliminary studies suggest structural resemblance for the $\mathrm{Cu}-\mathrm{Zr}$ and $\mathrm{Zr}-\mathrm{Zr}$ pairs between a glass and the B2 phase within the first-coordination cell with effectively no density difference between the two. The ductility of a metallic-glass/nanocrystal composite can be greatly enhanced from zero, for a glass, to $>10 \%$ for the composite; although the microstructure has not been fully optimized yet.

\section{Acknowledgements}

JO and IK acknowledge the financial support by the German Research Foundation DFG (Contract No. Ka-3209/9-1). We are also very grateful to Dr H. Siegel, Dr S. Ziller and Mrs B. Opitz for technical support. ALG acknowledges support from the European Research Council under the European Union's Horizon 2020 research and innovation programme (grant ERC-2015-AdG695487: Extend Glass). 


\section{References}

[1] M.F. Ashby, A.L. Greer, Metallic glasses as structural materials, Scr. Mater. 54 (2006) 321-326. https://doi.org/10.1016/j.scriptamat.2005.09.051.

[2] C. Suryanarayana, A. Inoue, Iron-based bulk metallic glasses, Int. Mater. Rev. 58 (2013) 131-166. https://doi.org/10.1179/1743280412Y.0000000007.

[3] P. Meagher, E.D. O’Cearbhaill, J.H. Byrne, D.J. Browne, Bulk metallic glasses for implantable medical devices and surgical tools, Adv. Mater. 28 (2016) 5755-5762. https://doi.org/10.1002/adma.201505347.

[4] A.L. Greer, Y.Q. Cheng, E. Ma, Shear bands in metallic glasses, Mater. Sci. Eng. R 74 (2013) 71-132. https://doi.org/10.1016/j.mser.2013.04.001.

[5] T. Egami, T. Iwashita, W. Dmowski, Mechanical properties of metallic glasses, Metals 3 (2013) 77-113. https://doi.org/10.3390/met3010077.

[6] F. Shimizu, S. Ogata, J. Li, Yield point of metallic glass, Acta Mater. 54 (2006) 4293-4298. https://doi.org/10.1016/j.actamat.2006.05.024.

[7] A. Das, P. Kagebein, S. Küchemann, R. Maaß, Temperature rise from fracture in Zr-based metallic glass, Appl. Phys. Lett. 112 (2018) 261905. https://doi.org/10.1063/1.5034762. [8] A.L. Greer, Metallic glasses, in: D. E. Laughlin, K. Hono (Eds.), Physical Metallurgy, Elsevier, 2014, pp. 305-385.

[9] F. Spaepen, A microscopic mechanism for steady state inhomogeneous flow in metallic glasses, Acta Metall. 25 (1977) 407-415. https://doi.org/10.1016/0001-6160(77)90232-2. [10] J. Schroers, W.L. Johnson, Ductile bulk metallic glass, Phys. Rev. Lett. 93 (2004) 255506. https://doi.org/10.1103/PhysRevLett.93.255506.

[11] C. Liu, R. Maaß, Elastic fluctuations and structural heterogeneities in metallic glasses, Adv. Funct. Mater. 28 (2018) 1800388. https://doi.org/10.1002/adfm.201800388.

[12] P. Zhang, J.J. Maldonis, Z. Liu, J. Schroers, P.M. Voyles, Spatially heterogeneous dynamics in a metallic glass forming liquid imaged by electron correlation microscopy, Nat. Commun. 8 (2018) 1129. https://doi.org/10.1038/s41467-018-03604-2.

[13] P.K. Gupta, D.R. Cassar, E.D. Zanotto, Role of dynamic heterogeneities in crystal nucleation kinetics in an oxide supercooled liquid, J. Chem. Phys. 145 (2016) 211920. https://doi.org/10.1063/1.4964674. 
[14] Y.H. Liu, D. Wang, K. Nakajima, W. Zhang, A. Hirata, T. Nishi, A. Inoue, M.W. Chen, Characterization of nanoscale mechanical heterogeneity in a metallic glass by dynamic force microscopy, Phys. Rev. Lett. 106 (2011) 125504.

https://doi.org/10.1103/PhysRevLett.106.125504.

[15] P. Ross, S. Küchemann, P.M. Derlet, H. Zu, W. Arnold, P. Liaw, K. Samwer, R. Maaß, Linking macroscopic rejuvenation to nano-elastic fluctuations in a metallic glass, Acta Mater. 138 (2017) 111-118. https://doi.org/10.1016/j.actamat.2017.07.043.

[16] J.-C. Lee, Calorimetric study of $\beta$-relaxation in an amorphous alloy: An experimental technique for measuring the activation energy for shear transformation, Intermetallics 44 (2014) 116-120. https://doi.org/10.1016/j.intermet.2013.09.002.

[17] S.V. Ketov, Y.H. Sun, S. Nachum, Z. Lu, A. Checchi, A.R. Beraldin, H.Y. Bai, W.H. Wang, D.V. Louzguine-Luzgin, M.A. Carpenter, A.L. Greer, Rejuvenation of metallic glasses by nonaffine thermal strain, Nature 524 (2015) 200-203. https://doi.org/10.1038/nature14674. [18] S. V. Ketov, A.S. Trifonov, Y.P. Ivanov, A.Y. Churyumov, A.V. Lubenchenko, A.A. Batrakov, J. Jiang, D.V. Louzguine-Luzgin, J. Eckert, J. Orava, A.L. Greer, On cryothermal cycling as a method for inducing structural changes in metallic glasses, NPG Asia Materials 10 (2018) 137-145. https://doi.org/10.1038/s41427-018-0019-4.

[19] Y. Sun, A. Concustell, A.L. Greer, Thermomechanical processing of metallic glasses: Extending the range of the glassy state, Nat. Rev. Mater. 1 (2016) 16039. https://doi.org/10.1038/natrevmats.2016.39.

[20] S. Küchemann, R. Maaß, Gamma relaxation in bulk metallic glasses, Scr. Mater. 137 (2017) 5-8. https://doi.org/10.1016/j.scriptamat.2017.04.034.

[21] D.H. Kim, W.T. Kim, E.S. Park, N. Mattern, J. Eckert, Phase separation in metallic glasses, Prog. Mater. Sci. 58 (2013) 1103-1172. https://doi.org/10.1016/j.pmatsci.2013.04.002.

[22] S. Scudino, J.J. Bian, H. Shakur Shahabi, D. Şopu, J. Sort, J. Eckert, G. Liu, Ductile bulk metallic glass by controlling structural heterogeneities, Sci. Rep. 8 (2018) 9174. https://doi.org/10.1038/s41598-018-27285-5.

[23] Q. An, K. Samwer, W.A. Goddard, III, W.L. Johnson, A. Jaramillo-Botero, G. Garret, M.D. Demetriou, Predicted optimum composition of the glass-forming ability of bulk amorphous alloys: Application to Cu-Zr-Al, J. Phys. Chem. Lett. 3 (2012) 3143-3148. http://dx.doi.org/10.1021/jz3014425. 
[24] A. Inoue, A. Takeuchi, Recent development and application products of bulk glassy alloys, Acta Mater. 59 (2011) 2243-2267. https://doi.org/10.1016/j.actamat.2010.11.027.

[25] S. Zhang, T. Ichitsubo, Y. Yokoyama, T. Yamamoto, E. Matsubara, A. Inoue, Crystallization behavior and structural stability of $\mathrm{Zr}_{50} \mathrm{Cu}_{40} \mathrm{Al}_{10}$ bulk metallic glass, Mater. Trans. 50 (2009) 1340-1345. https://doi.org/10.2320/matertrans.MBW200833.

[26] W.H. Wang, J.J. Lewandowski, A.L. Greer, Understanding the glass-forming ability of $\mathrm{Cu}_{50} \mathrm{Zr}_{50}$ alloys in terms of metastable eutectic, J. Mater. Res. 20 (2005) 2307-2313. https://doi.org/10.1557/jmr.2005.0302.

[27] J.M. Silveyra, E. Ferrara, D.L. Huber, T.C. Monson, Soft magnetic materials for a sustainable and electrified world, Science 362 (2018) eaa0195.

https://doi.org/10.1126/science.aao0195.

[28] E. Zhuravlev, V. Madhavi, A. Lustiger, R. Androsch, C. Schick, Crystallization of polyethylene at large undercooling, ACS Macro Lett. 5 (2016) 365-370.

https://doi.org/10.1021/acsmacrolett.5b00889.

[29] C. Schick, M. Vincent, Fast Scanning Calorimetry, Springer, 2016.

[30] S. Pogatscher, D. Leutenegger, J.E.K. Schawe, P. Maris, R. Schäublin, P.J. Uggowitzer, J.F. Löffler, Monotropic polymorphism in a glass-forming metallic alloy, J. Phys.: Condens. Matter. 30 (2018) 234002. https://doi.org/10.1088/1361-648X/aac054.

[31] B. Yang, J.W.P. Schmelzer, B. Zhao, Y. Gao, C. Schick, Glass transition and primary crystallization of $\mathrm{Al}_{86} \mathrm{Ni}_{6} \mathrm{Y}_{4.5} \mathrm{Co}_{2} \mathrm{La}_{1.5}$ metallic glass at heating rates spanning over six orders of magnitude, Scr. Mater. 162 (2019) 146-150. https://doi.org/10.1016/j.scriptamat.2018.11.014. [32] D.H. Kang, I.-H. Jung, Critical thermodynamic evaluation and optimization of the Ag-Zr, $\mathrm{Cu}-\mathrm{Zr}$ and $\mathrm{Ag}-\mathrm{Cu}-\mathrm{Zr}$ systems and its applications to amorphous $\mathrm{Cu}-\mathrm{Zr}-\mathrm{Ag}$ alloys, Intermetallics 18 (2010) 815-833. https://doi.org/10.1016/j.intermet.2009.12.013.

[33] I. Kalay, M.J. Kramer, R.E. Napolitano, High-accuracy x-ray diffraction analysis of phase evolution sequence during devitrification of $\mathrm{Cu}_{50} \mathrm{Zr}_{50}$ metallic glass, Metall. Mater. Trans. A 42A (2011) 1144-1153. https://doi.org/10.1007/s11661-010-0531-9.

[34] M.H. Braga, L.F. Malheiros, F. Castro, D. Soares, Experimental liquidus points and invariant reactions in the $\mathrm{Cu}-\mathrm{Zr}$ system, Z. Metallkd. 89 (1998) 541-545.

[35] J.L. Glimois, P. Forey, J.L. Feron, Structural and physical studies of copper-rich alloys in the Cu-Zr system, J. Less-Common Met. 113 (1985) 213-224. 
[36] D.L. Douglas, R.E. Morgan, The determination of solid solubilities by quantitative metallography of a single alloy, Trans. Metall. Soc. AIME 215 (1959) 869-870.

[37] M.J. Saarivirta, High conductivity copper-rich Cu-Zr alloys, Trans. Metall. Soc. AIME 218 (1960) 431-437.

[38] G.M. Kuznetsov, V.N. Fyodorov, A.L. Rodnyanskaya, I.V. Nikolaeva, Investigating of the phase diagram of the $\mathrm{Cu}-\mathrm{Zr}$ system, Tsvetn. Met. 6 (1978) 267-268.

[39] E. Raub, M. Engel, The alloys of zirconium with copper, silver and gold, Z. Metallkd. 39 (1948) 172-177.

[40] K. Yamaguchi, Y.C. Song, T. Yoshida, K. Itagaki, Thermodynamic investigation of the CuZr system, J. Alloys Compd. 452 (2008) 73-79. https://doi.org/10.1016/j.jallcom.2007.01.173.

[41] https://matdata.asminternational.org/apd/index.aspx (accessed January 2019).

[42] L. Tretyachenko, Al-Cu-Zr, in: G. Effenberg, S. Ilyenko (Eds.), Light Metal Ternary Systems Part 2, Springer, Berlin, (2005), pp. 206-222. https://doi.org/10.1007/10915967_14. [43] J. Das, M.B. Tang, K.B. Kim, R. Theissmann, F. Baier, W.H. Wang, J. Eckert, „Workhardenable“ ductile bulk metallic glass, Phys. Rev. Lett. 94 (2005) 205501. https://doi.org/10.1103/PhysRevLett.94.205501.

[44] S. Pauly, J. Das, C. Duhamel, J. Eckert, Martensite formation in a ductile $\mathrm{Cu}_{47.5} \mathrm{Zr}_{47.5} \mathrm{Al}_{5}$ bulk metallic glass composite, Adv. Eng. Mater. 9 (2007) 487-491. https://doi.org/10.1002/adem.200700044.

[45] J. Eckert, U. Kühn, N. Mattern, G. He, A. Gebert, Structural bulk metallic glasses with different length-scale of constituent phases, Intermetallics 10 (2002) 1183-1190. https://doi.org/10.1016/S0966-9795(02)00133-4.

[46] Y. Wu, H. Wang, H.H. Wu, Z.Y. Zhang, X.D. Hui, G.L. Chen, D. Ma, X.L. Wang, Z.P. Lu, Formation of $\mathrm{Cu}-\mathrm{Zr}-\mathrm{Al}$ bulk metallic glass composites with improved tensile properties, Acta Mater. 59 (2011) 2928-2936. https://doi.org/10.1016/j.actamat.2011.01.029.

[47] T. Kozieł, Estimation of cooling rates in suction casting and copper-mould casting processes, Arch. Metall. Mater. 60 (2015) 767-771. https://doi.org/10.1515/amm-2015-0204. [48] S. Sohn, Y. Jung, Y. Xie, C. Osuji, J. Schroers, J.J. Cha, Nanoscale size effects in crystallization of metallic glass nanorods, Nat. Commun. 6 (2015) 8157. https://doi.org/10.1038/ncomms9157. 
[49] S. Sohn, Y. Xie, Y. Jung, J. Schroers, J.J. Cha, Tailoring crystallization phases in metallic glass nanorods via nucleation starvation, Nat. Commun. 8 (2017) 1980.

https://doi.org/10.1038/s41467-017-02153-4.

[50] T. Zhang, A. Inoue, Bulk glassy alloys with low liquidus temperature in $\mathrm{Pt}-\mathrm{Cu}-\mathrm{P}$ system, Mater. Trans. A 44 (2003) 1143-1146. https://doi.org/10.2320/matertrans.44.1143.

[51] J. Schroers, W.L. Johnson, Crystallization kinetics of the bulk-glass-forming $\mathrm{Pd}_{43} \mathrm{Ni}_{10} \mathrm{Cu}_{27} \mathrm{P}_{20}$ melt, Appl. Phys. Lett. 77 (2000) 1158-1160. https://doi.org/10.1063/1.1289033. [52] I.V. Okulov, I.V. Soldatov, M.F. Sarmanova, I. Kaban, T. Gemming, K. Edström, J. Eckert, Flash Joule heating for ductilization of metallic glasses, Nat. Commun. 6 (2015) 7932. https://doi.org/10.1038/ncomms8932.

[53] K. Kosiba, S. Pauly, Inductive flash-annealing of bulk metallic glasses, Sci. Rep. 7 (2017) 2151. https://doi.org/10.1038/s41598-017-02376-x.

[54] W.L. Johnson, G. Kaltenboeck, M.D. Demetriou, J.P. Schramm, X. Liu, K. Samwer, C.P. Kim, D.C. Hofmann, Beating crystallization in glass-forming metals by millisecond heating and processing, Science 332 (2011) 828-833. https://doi.org/10.1126/science.1201362.

[55] S. Küchemann, K. Samwer, Ultrafast heating of metallic glasses reveals disordering of the amorphous structure, Acta Mater. 104 (2016) 119-124.

https://doi.org/10.1016/j.actamat.2015.11.039.

[56] I. Kaban, K, Khalouk, F. Gasser, J.-G. Gasser, J. Bednarčik, O. Shuleshova, I. Okulov, T. Gemming, N. Mattern, J. Eckert, In situ studies of temperature-dependent behavior and crystallization of $\mathrm{Ni}_{36.5} \mathrm{Pd}_{36.5} \mathrm{P}_{27}$ metallic glass, J. Alloys Compd. 615 (2014) S208-S212. https://doi.org/10.1016/j.jallcom.2013.12.259.

[57] K.K. Song, X.L. Han, S. Pauly, Y.S. Qin, K. Kosiba, C.X. Peng, J.H. Gong, P.X. Chen, L. Wang, B. Sarac, S. Ketov, M. Mühlbacher, F. Spieckermann, I. Kaban, J. Eckert, Rapid and partial crystallization to design ductile CuZr-based bulk metallic glass composites, Mater. Des. 139 (2018) 132-140. https://doi.org/10.1016/j.matdes.2017.11.008.

[58] K. Kosiba, S. Scudino, R. Kobold, U. Kühn, A.L. Greer, J. Eckert, S. Pauly, Transient nucleation and microstructural design in flash-annealed bulk metallic glasses, Acta Mater. 127 (2017) 416-425. https://doi.org/10.1016/j.actamat.2017.01.059. 
[59] T. Cullinan, I. Kalay, Y.E. Kalay, M. Kramer, R. Napolitano, Kinetics and mechanism of isothermal devitrification in amorphous $\mathrm{Cu}_{50} \mathrm{Zr}_{50}$, Metall. Mater. Trans. A 46A (2015) 600-613. https://doi.org/10.1007/s11661-014-2661-y.

[60] I. Kalay, M.J. Kramer, R.E. Napolitano, Crystallization kinetics and phase transformation mechanisms in $\mathrm{Cu}_{56} \mathrm{Zr}_{44}$ glassy alloy, Metall. Mater. Trans. A 46A (2015) 3356-3364. https://doi.org/10.1007/s11661-015-2921-5.

[61] D.Y. Wu, K.K. Song, P. Gargarella, C.D. Cao, R. Li, I. Kaban, J. Eckert, Glass-forming ability, thermal stability of B2 CuZr phase, and crystallization kinetics for rapidly solidified $\mathrm{Cu}-\mathrm{Zr}-\mathrm{Zn}$ alloys, J. Alloys Compd. 664 (2016) 99-108.

https://doi.org/10.1016/j.jallcom.2015.12.187.

[62] I. Kaban, P. Jovari, B. Escher, D.T. Tran, G. Svenson, M.A. Webb, T.Z. Regier, V. Kokotin, B. Beneu, T. Gemming, J. Eckert, Atomic structure and formation of CuZrAl bulk metallic glasses and composites, Acta Mater. 100 (2015) 369-376.

https://doi.org/10.1016/j.actamat.2015.08.060.

[63] I. Kalay, Devitrification kinetics and phase selection mechanisms in $\mathrm{Cu}-\mathrm{Zr}$ metallic glasses, Graduate Theses and Dissertations, Iowa State University, 2010, paper 11890. https://doi.org/10.31274/etd-180810-1288.

[64] S. Pauly, J. Das, N. Mattern, D.H. Kim, J. Eckert, Phase formation and thermal stability in $\mathrm{Cu}-\mathrm{Zr}-\mathrm{Ti}(\mathrm{Al})$ metallic glasses, Intermetallics 17 (2009) 453-462.

https://doi.org/10.1016/j.intermet.2008.12.003.

[65] H. Yasuda, D. Nagamatsu, T. Yoshimoto, T. Nagira, M. Yoshiya, Y. Yokoyama, A. Inoue, Crystal growth in the bulk-metallic-glass $\mathrm{Zr}$-based alloys by using the $\mathrm{DC}+\mathrm{AC}$ levitation method, J. Phys.: Conf. Ser. 155 (2009) 012056. https://doi.org/10.1088/1742$\underline{6596 / 144 / 1 / 012056 .}$

[66] V. Kokotin, H. Hermann, J. Eckert, Computer simulation of the matrix-inclusion interphase in bulk metallic glass based nanocomposites, J. Phys.: Condens. Matter. 23 (2011) 425403. http://dx.doi.org/10.1088/0953-8984/23/42/425403.

[67] Q. Wang, L.-M. Wang, M.Z. Ma, S. Binder, T. Volkmann, D.M. Herlach, J.S. Wang, Q.G. Xue, Y.J. Tian, R.P. Liu, Diffusion-controlled crystal growth in deeply undercooled melt on approaching the glass transition, Phys. Rev. B 83 (2011) 014202.

https://doi.org/10.1103/PhysRevB.83.014202. 
[68] J. Orava, A. L. Greer, Fast and slow crystal growth kinetics in glass-forming liquids, J. Chem. Phys. 140 (2014) 214504. https://doi.org/10.1063/1.4880959.

[69] K.K. Song, S. Pauly, Y. Zhang, P. Gargarella, R. Li, N. S. Barekar, U. Kühn, M. Stoica, J. Eckert, Strategy for pinpointing the formation of B2 CuZr in metastable CuZr-based shape memory alloys, Acta Mater. 59 (2011) 6620-6630.

https://doi.org/10.1016/j.actamat.2011.07.017.

[70] S. Küchemann, G. Gibbins, J. Corkerton, E. Brug, J. Ruebsam, K. Samwer, From ultrafast to slow: Heating rate dependence of the glass transition temperature in metallic systems, Philos. Mag. Lett. 96 (2016) 454-460. https://doi.org/10.1080/09500839.2016.1251623.

[71] K. Albe, Y. Ritter, D. Şopu, Enhancing the plasticity of metallic glasses: Shear band formation, nanocomposites and nanoglasses investigated by molecular dynamics simulations, Mech. Mater. 67 (2013) 94-103. https://doi.org/10.1016/j.mechmat.2013.06.004.

[72] T. Bring, M. Peterlechner, H. Rösner, K. Albe, G. Wilde, Influence of crystalline nanoprecipitates on shear-band propagation in $\mathrm{Cu}$-Zr-based metallic glasses, Phys. Rev. Appl. 5 (2016) 054005. https://doi.org/10.1103/PhysRevApplied.5.054005.

[73] T. Bring, K. Albe, From metallic glasses to nanocrystals: Molecular dynamics simulations on the crossover from glass-like to grain-boundary-mediated deformation behaviour, Acta Mater. 156 (2018) 205-214. https://doi.org/10.1016/j.actamat.2018.06.036.

[74] Y. Shi, M.L. Falk, A computational analysis of the deformation mechanisms of a nanocrystal-metallic glass composite, Acta Mater. 56 (2008) 995-1000.

https://doi.org/10.1016/j.actamat.2007.11.005.

[75] D.V. Louzguine, A.R. Yavari, K. Ota, G. Vaughan, A. Inoue, Synchrotron X-ray radiation studies of thermal expansion, free volume change and glass transition phenomenon in $\mathrm{Cu}$-based glassy and nanocomposite alloys on heating, J. Non-Cryst. Solids 351 (2005) 1639-1645. https://doi.org/10.1016/j.jnoncrysol.2005.04.054.

[76] F. Jiang, Y. Zhao, L. Zhang, S. Pan, Y. Zhou, L. He, J. Sun, The coupling effect of small nanocrystals and free volume on the ductility of $\mathrm{Cu}_{46} \mathrm{Zr}_{47} \mathrm{Al}_{7}$ bulk metallic glass alloy, Adv. Eng. Mater. 11 (2009) 374-379. https://doi.org/10.1002/adem.200800363.

[77] K. Hajlaoui, N.H. Alrasheedi, A.R. Yavari, Direct observation of shear-induced nanocrystal attachment and coalescence in CuZr-based metallic glasses: TEM observation, J. Alloys Compd. 665 (2016) 339-344. https://doi.org/10.1016/j.jallcom.2016.01.017. 
[78] J. He, I. Kaban, N. Mattern, K. Song, B. Sun, J. Zhao, D.H. Kim, J. Eckert, A.L. Greer, Local microstructure evolution at shear bands in metallic glasses with nanoscale phase separation, Sci. Rep. 6 (2016) 25832. https://doi.org/10.1038/srep25832.

[79] N. Matsumoto, R. Matsumoto, N. Miyazaki, Estimation of shear-banding resistance in metallic glass containing nano-crystalline particles, J. Non-Cryst. Solids 355 (2009) 29-32. https://doi.org/10.1016/j.jnoncrysol.2008.09.034.

[80] V. Kokotin, H. Hermann, J. Eckert, Theoretical approach to local and effective properties of BMG based matrix-inclusion nanocomposites, Intermetallics 30 (2012) 40-47.

https://doi.org/10.1016/j.intermet.2012.03.042.

[81] S. Pauly, S. Gorantla, G. Wang, U. Kühn, J. Eckert, Transformation-mediated ductility in CuZr-based bulk metallic glasses, Nat. Mater. 9 (2010) 473-477.

https://doi.org/10.1038/nmat2767.

[82] J. Corteen, M. Rainforth, I. Todd, A mathematical approach to transformation toughening in bulk metallic glasses, Scr. Mater. 65 (2011) 524-527.

https://doi.org/10.1016/j.scriptamat.2011.06.018.

[83] K.K. Song, S. Pauly, Y. Zhang, R. Li, S. Gorantla, N. Narayanan, U. Kühn, T. Gemming, J. Eckert, Triple yield and deformation mechanisms in metastable $\mathrm{Cu}_{47.5} \mathrm{Zr}_{47.5} \mathrm{Al}_{5}$ composites, Acta Mater. 60 (2012) 6000-6012. https://doi.org/10.1016/j.actamat.2012.07.015. 


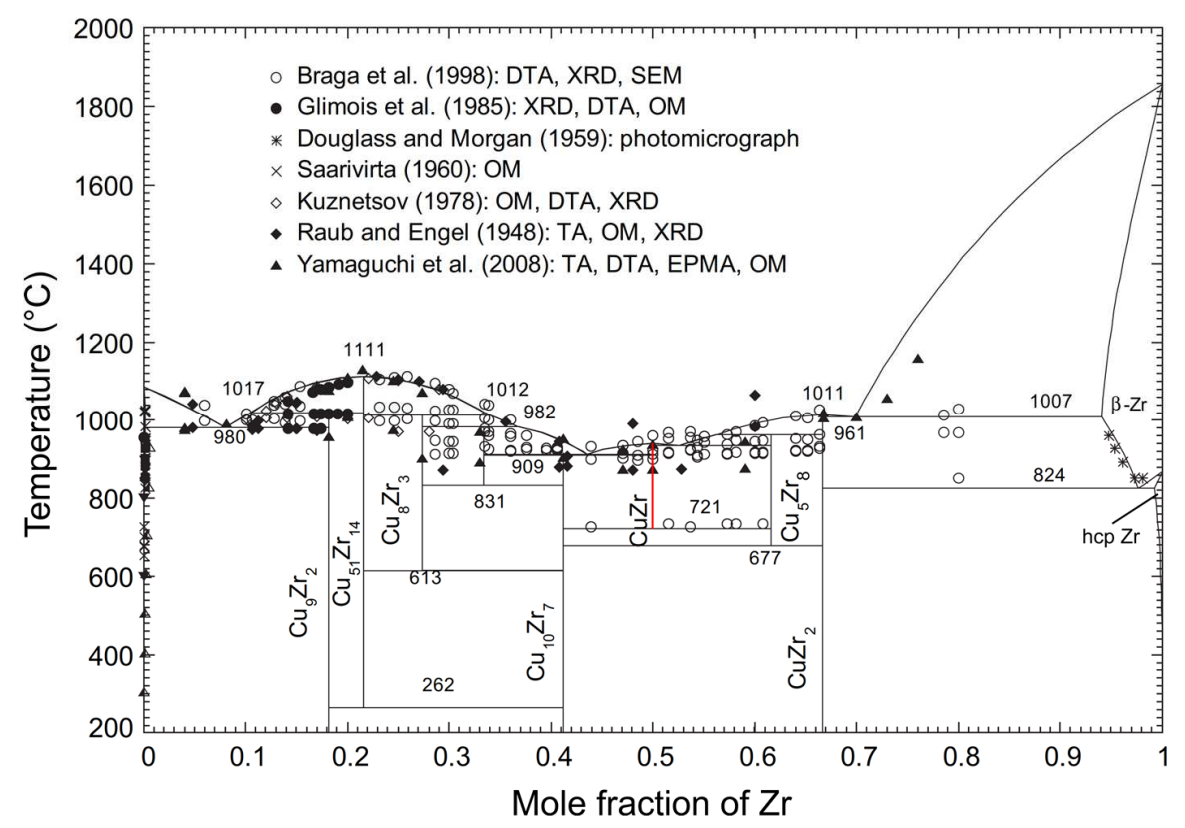

Fig. 1. The equilibrium phase diagram of the binary $\mathrm{Cu}-\mathrm{Zr}$ system. The congruently melting austenitic high-temperature B2-CuZr phase, highlighted in red, is stable between $721-938^{\circ} \mathrm{C}$. See Table 1 for the list of the known metastable phases. The individual data points can be found in the work of Braga et al. [34]; Glimois et al. [35]; Douglas and Morgan [36]; Saarivirta [37]; Kuznetsov [38]; Raub and Engel [39]; and Yamaguchi et al. [40] (DTA - differential thermal analysis, XRD - X-ray diffraction, SEM - scanning electron microscopy, OM - optical microscopy, TA - thermal analysis, EPMA - electron-probe-micro analyzer). Published with permission from Ref. [32]. 


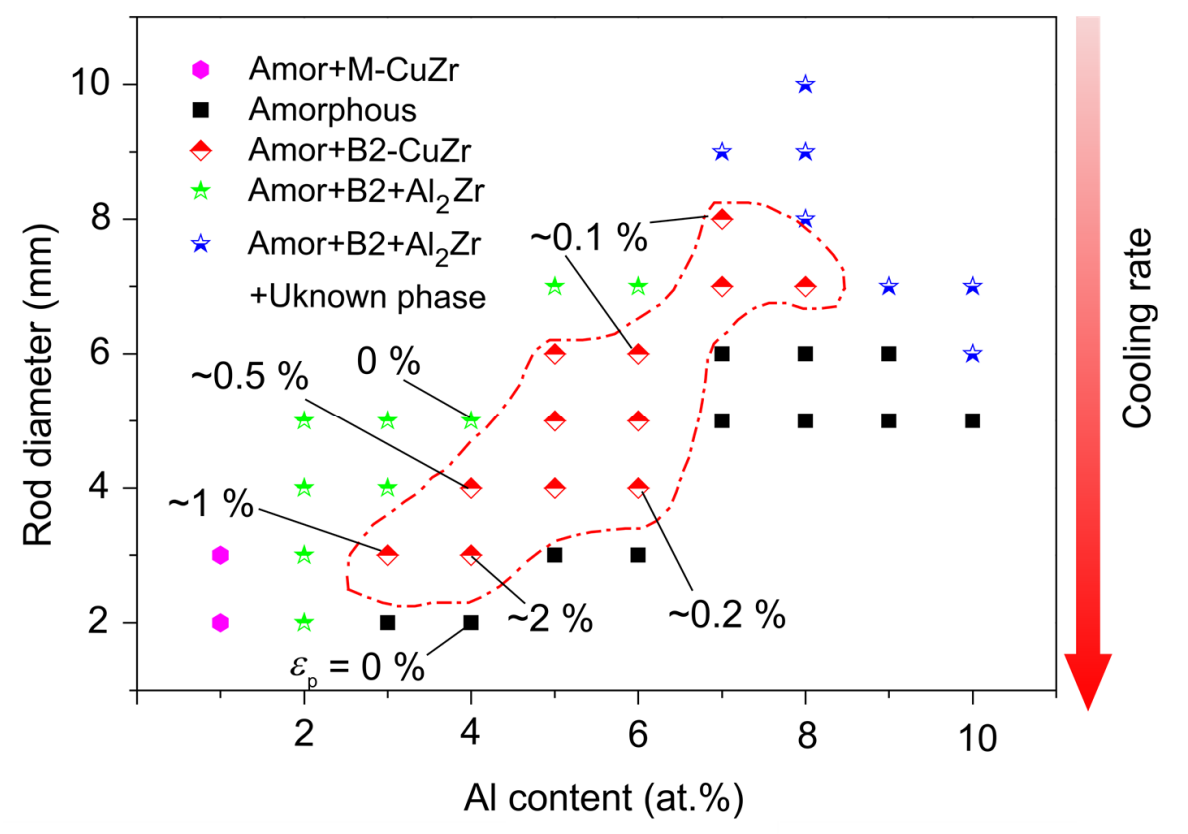

Fig. 2. The cooling-rate, represented by a rod diameter, dependent trends in the final microstructure and ductility, $\varepsilon_{\mathrm{p}}$, for the ternary $\left(\mathrm{Cu}_{0.5} \mathrm{Zr}_{0.5}\right)_{x} \mathrm{Al}_{100-x}$ metallic glass. The beneficial region of the glass/B2-CuZr composites formation (diamonds) is outlined by the red dashed line. The estimated cooling rates are $\sim 200-250 \mathrm{~K} \mathrm{~s}^{-1}$ for 2-mm diameter rod and $\sim 30 \mathrm{~K} \mathrm{~s}^{-1}$ for 5-mm diameter rod for a suction-casting method by using a copper mold [47]. Published and modified with permission from Ref. [46]. 


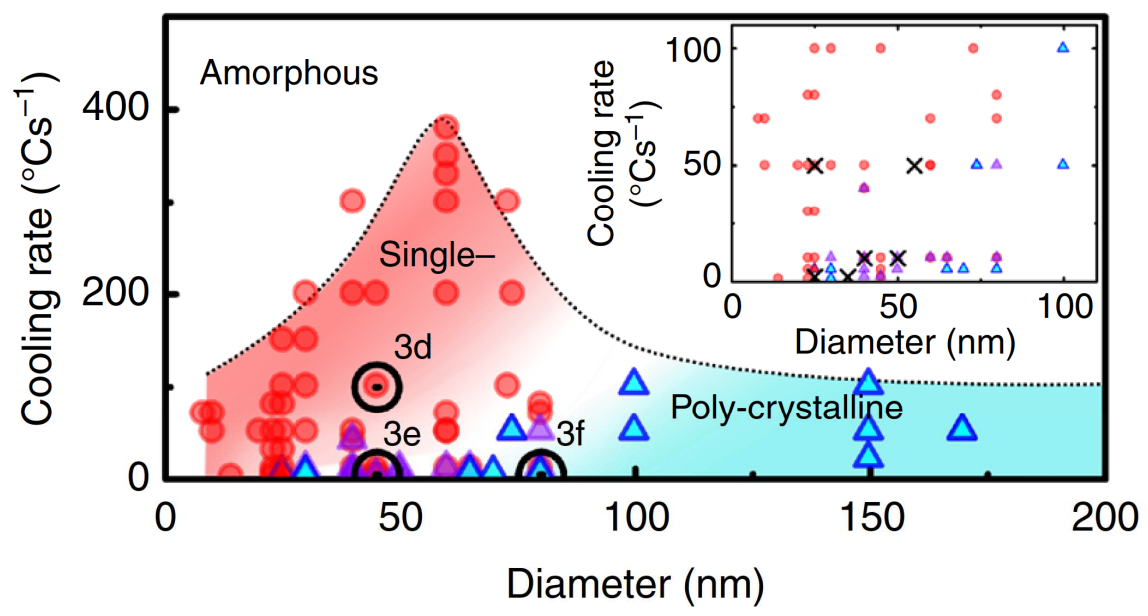

Fig. 3. A phase diagram showing the size-dependent crystallization for $\mathrm{Pt}_{57.5} \mathrm{Cu}_{14.7} \mathrm{Ni}_{5.3} \mathrm{P}_{22.5}$ glassy rods. The rod microstructure changes from containing an apparent single-crystalline phase (red circles), to a polycrystalline phase with the same composition to the glass (purple triangles), and to containing a polycrystalline phase (blue triangles) with different chemical compositions with increasing the rod diameter. The complex polycrystalline crystallization is dominant for rods with the diameter of $\sim 100 \mathrm{~nm}$ and larger. The black dotted line shows the critical cooling rate (for glass formation) for a given rod diameter. Inset shows the magnification of the small-diameter region. Please refer to the original work for the interpretation of the other symbols. Published from Ref. [49] under a creative common license (http://creativecommons.org/licenses/by/4.0/). 

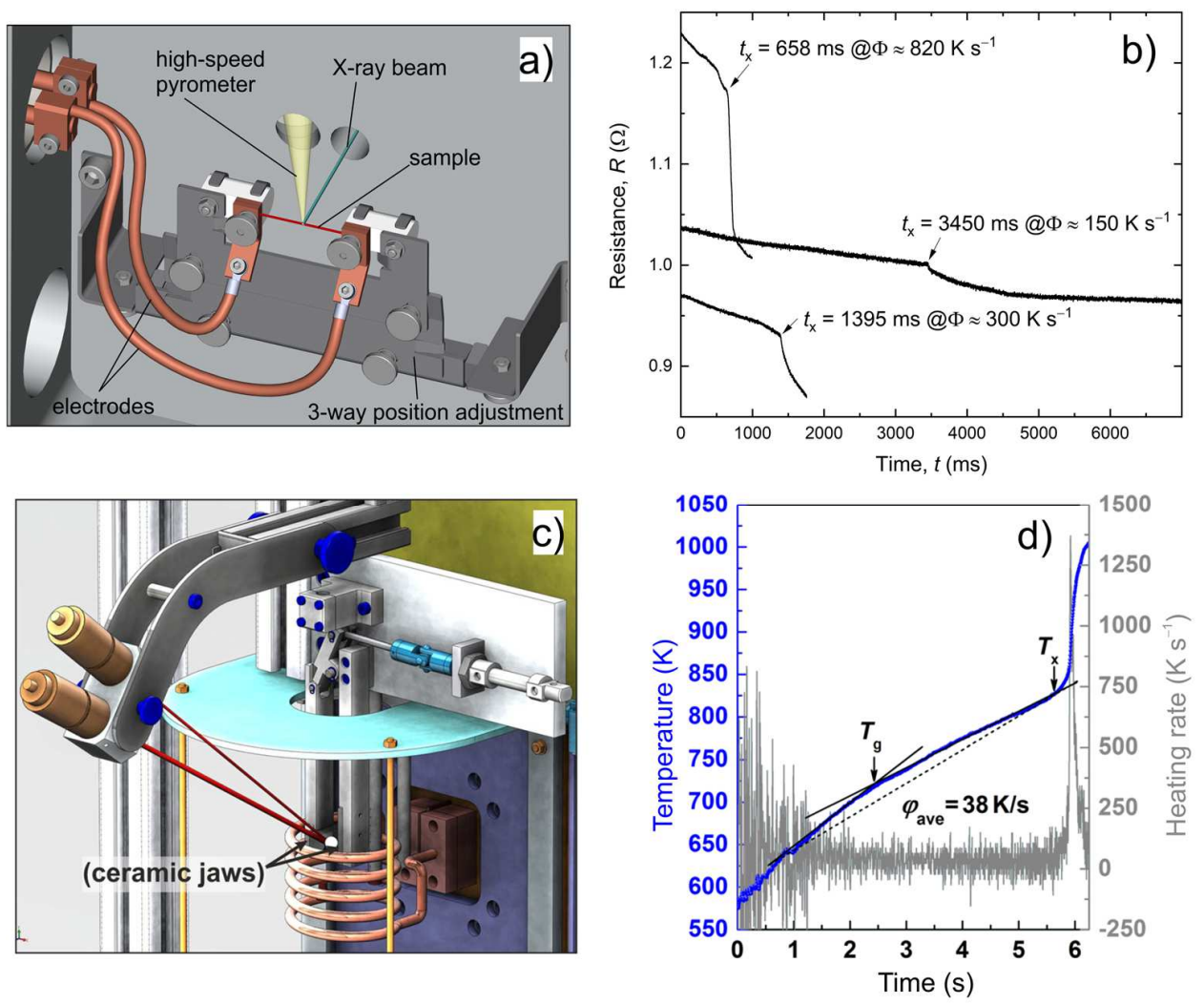

Fig. 4. a) Schematic of a rapid-resistive-heating setup, heating rate of up to $\sim 10^{3} \mathrm{~K} \mathrm{~s}^{-1}$, employing in-situ X-ray measurements of metallic-glassy ribbons, typically $\sim 5 \mathrm{~cm}$ long, $\sim 1-2 \mathrm{~mm}$ wide and $<40 \mu \mathrm{m}$ thick, in a controlled atmosphere (the full-size chamber is not shown). b) A typical temperature-dependent resistance for $\mathrm{Cu}-\mathrm{Zr}-\mathrm{Al}$ ribbons with the onset of crystallization marked by the resistance drop. The slope of the temperature dependence before the onset of crystallization correlates with the relative position of the Fermi vector to the main peak of the structure factor [56]. c) Schematic of induction heating of bulk-metallic glasses (a high-speed pyrometer recording sample surface temperature - left; and a water-cooled induction coil and ceramic jaws for placing a sample, the white spot, are shown). d) The recorded temperature profile, heating rate of $\sim 38 \mathrm{~K}$ $\mathrm{s}^{-1}$, highlighting the glass-transition temperature, $T_{\mathrm{g}}$, and the crystallization onset, $T_{\mathrm{x}}$, for $\mathrm{Zr}_{52.5} \mathrm{Cu}_{17.9} \mathrm{Ni}_{14.6} \mathrm{Al}_{10} \mathrm{Ti}_{5}$ bulk-metallic glass. Parts $c$ and $d$ are published from Ref. [53] under $a$ creative common license (http://creativecommons.org/licenses/by/4.0/). 
a)

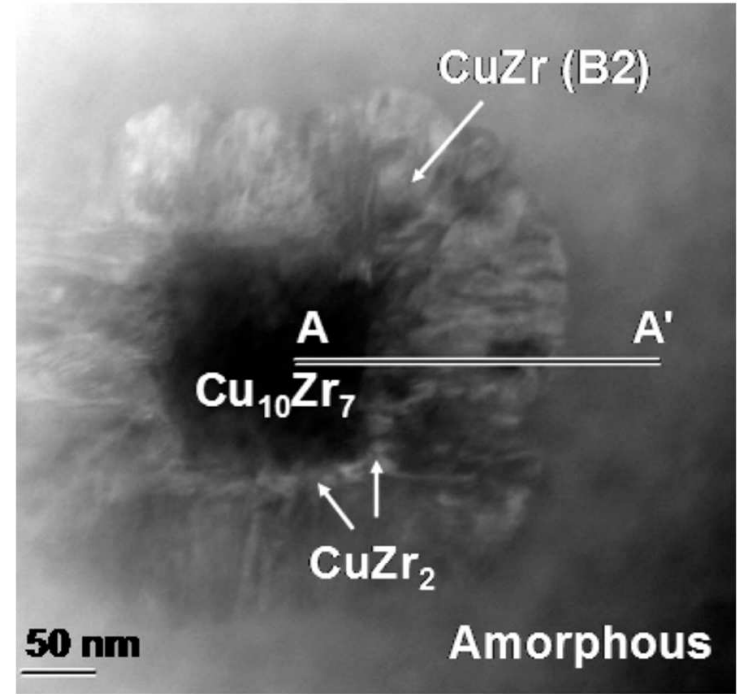

b)

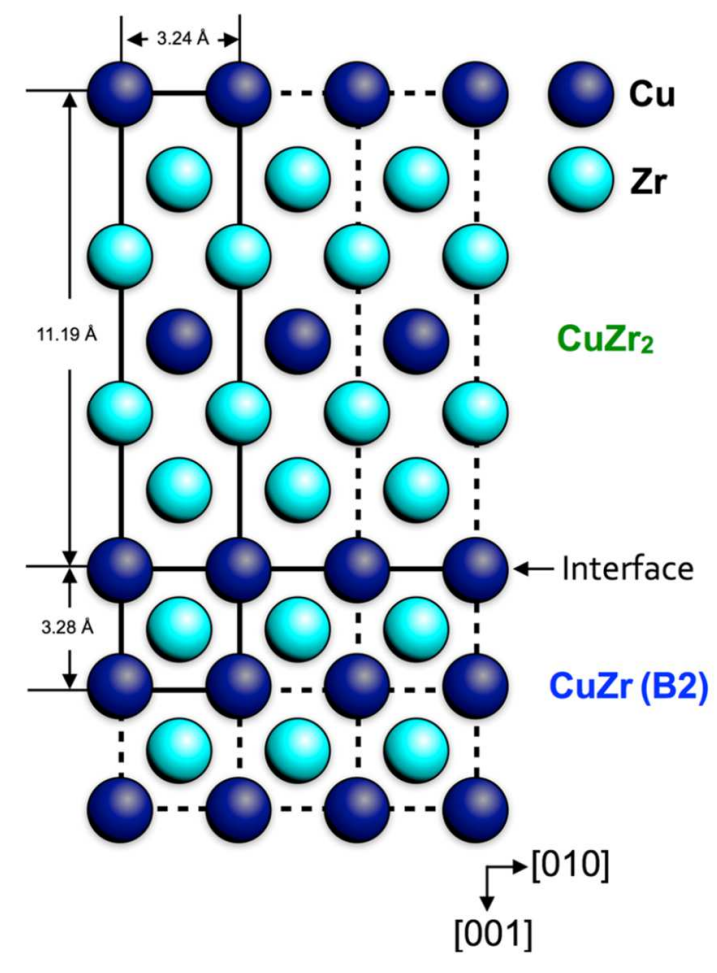

Fig. 5. a) Transmission electron micrograph of $\mathrm{Cu}_{50} \mathrm{Zr}_{50}$ glassy ribbon annealed at $671 \mathrm{~K}$ for 44 minutes. The final composite microstructure consists of four phases: $\mathrm{Cu}_{10} \mathrm{Zr}_{7} / \mathrm{CuZr}_{2} / \mathrm{B} 2-\mathrm{CuZr}$ crystal-growth sequence and the remaining glassy phase. b) Schematic of an epitaxial-like templating of the B2-CuZr phase formation via small atomic re-arrangements in the $\mathrm{CuZr}_{2}$ phase. Published with permission from Ref. [59]. 


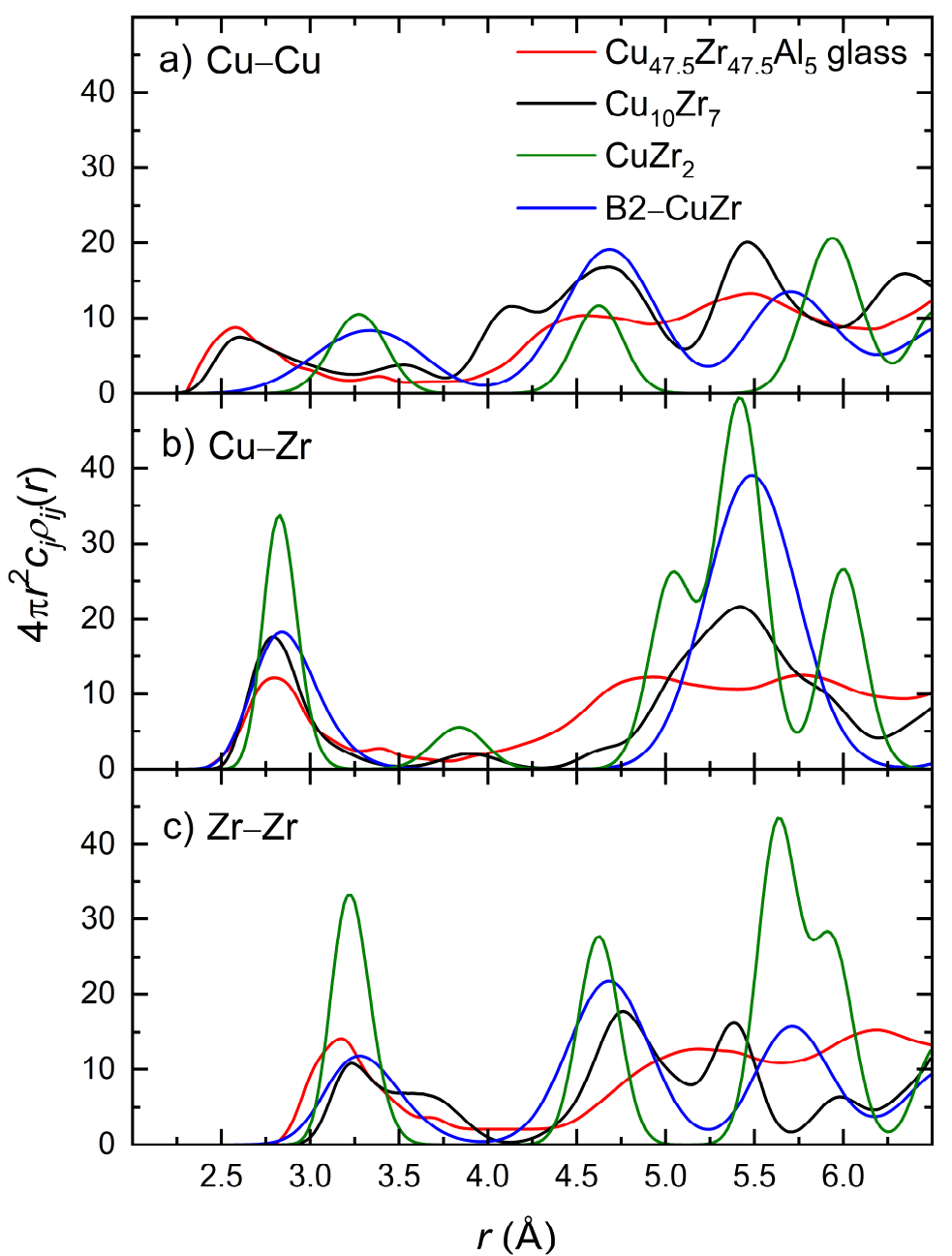

Fig. 6. The comparison of the partial radial distribution functions for a) $\mathrm{Cu}-\mathrm{Cu}, \mathrm{b}) \mathrm{Cu}-\mathrm{Zr}$, and c) $\mathrm{Zr}-\mathrm{Zr}$ pairs for $\mathrm{Cu}_{47.5} \mathrm{Cu}_{47.5} \mathrm{Al}_{5}$ glass, $\mathrm{Cu}_{10} \mathrm{Zr}_{7}, \mathrm{~B} 2-\mathrm{CuZr}$ and $\mathrm{CuZr}_{2}$ crystalline phases. Adapted from Ref. [62]. 
Table 1. The reported metastable crystalline phases in the binary $\mathrm{Cu}-\mathrm{Zr}$ system. The data are taken from Ref. [33] (also see the references therein for the original reports of the individual phases).

\begin{tabular}{cccc}
\hline Composition & Prototype & Structure & Space group \\
\hline $\mathrm{Cu}_{7} \mathrm{Zr}_{2}$ & - & - & $\mathrm{C} 2 / \mathrm{m}$ \\
$\mathrm{Cu}_{3} \mathrm{Zr}$ & - & - & $\mathrm{P}_{3} / \mathrm{mmc}$ \\
$\mathrm{CuZr}$ & - & $\mathrm{B} 19^{\prime}$ & $\mathrm{P} 2_{1} / \mathrm{m}$ \\
$\mathrm{CuZr}$ & - & $\mathrm{B} 33$ & $\mathrm{Cmcm}$ \\
$\mathrm{CuZr}$ & $\gamma \mathrm{CuTi}$ & $\mathrm{B} 11$ & $\mathrm{P} 4 / \mathrm{nmm}$ \\
$\mathrm{CuZr}$ & $\mathrm{AuCu}-\mathrm{I}$ & $\mathrm{L} 1_{0}$ & $\mathrm{P} 4 / \mathrm{mmm}$ \\
$\mathrm{CuZr}$ & $\beta-\mathrm{AuCd}$ & $\mathrm{B} 19$ & $\mathrm{Pmma}$ \\
\hline
\end{tabular}

